\title{
Amino acid requirements of the breeding sow
}

\section{2. *The dietary lysine requirement of the lactating sow}

\author{
By M. A. SOHAIL, $\uparrow$ D. J. A. COLE $\ddagger$ AND D. LEWIS \\ University of Nottingham School of Agriculture, \\ Sutton Bonington, Loughborough, Leics. LEI2 $5 R D$
}

(Received 5 November 1977 - Accepted 4 January 1978)

\begin{abstract}
I. Two experiments, involving six lactating Landacre $\times$ (Landrace $\times$ Large White) sows were undertaken to study the lysine requirement of the lactating sow and to identify the second limiting amino acid by means of interpretation of plasma amino acid and blood urea levels.

2. A basal diet composed mainly of equal amounts of ground barley and ground wheat supplemented with mineral and vitamin mixtures was used. This diet was supplemented with synthetic amino acids (lysine, threonine, tryptophan, methionine and isoleucine).

3. Plasma amino acid and blood urea values showed a close agreement and indicated that lysine intake above $38.4 \mathrm{~g} / \mathrm{d}$ was in excess of the requirement level.

4. Plasma amino acid values suggested tryptophan to be the second limiting amino acid whereas blood urea values suggested threonine to be the second limiting amino acid.
\end{abstract}

It has been stressed (Agricultural Research Council, 1967) that the published information on which to assess the protein and amino acid requirements of the breeding sow is limited. Several authors (e.g. Speer, I97I ; Elsley \& MacPherson, 1972) have reviewed this subject but there is no general agreement concerning amino acid requirements.

Lewis \& Speer (1973) indicated that a mature sow requires a minimum of $5 \mathrm{~g}$ lysine $/ \mathrm{kg}$ diet whereas Salmon-Legagneur \& Duee (1972) suggested that 6.9 glysine $/ \mathrm{kg}$ diet was necessary during lactation. Scale of feeding, weight of animal, litter size, stage of lactation and other factors will of course affect a value expressed in these terms.

The present study comprised two experiments. In Expt I the lysine requirement of the lactating sow was studied by determination of plasma amino acid and blood urea levels. In Expt 2 the effects of dietary essential amino acid supplementation on plasma amino acid and blood urea levels was investigated with a view to identifying the second limiting amino acid in cereal-based diets for the lactating sows. A preliminary account of this work has been published (Sohail, Cole \& Lewis, I974).

\section{MATERIAL AND METHODS}

Expt. I. Four Landrace $\times$ (Landrace $\times$ Large White) lactating sows were selected on the $4^{\text {th }}$ day of lactation and housed in metabolism crates. The litters were standardized to six piglets. They were offered a basal diet containing $126 \mathrm{~g}$ crude protein (nitrogen $\times 6.25$ ) $/ \mathrm{kg}$ dry matter (DM). The composition of the basal diet has been described previously (Sohail, Cole \& Lewis, 1978). The basal diet was supplemented with L-lysine hydrochloride to achieve six levels of dietary lysine: $3 \cdot 7,5 \cdot 7,7 \cdot 7,9 \cdot 7$, II 7 and $13.7 \mathrm{~g} / \mathrm{kg} \mathrm{DM}$. The actual daily lysine intakes were $14 \cdot 59,22 \cdot 50,30 \cdot 45,38 \cdot 40,46 \cdot 35$ and $54 \cdot 26 \mathrm{~g}$ respectively.

* Paper no. 1, Br.J. Nutr. (1978), 39, 463.

$\dagger$ Present address: Spillers Ltd, Kennett Nutritional Centre and Pet Care Unit, Kennett, Nr Newmarket, Suffolk.

$\ddagger$ For reprints. 
Table I. Amino acid supplementation of the basal diet

$\begin{array}{ccc}\text { Dietary treatments } & \begin{array}{c}\text { Supplement } \\ \text { (g/kg DM) }\end{array} & \begin{array}{c}\text { Intake } \\ (\mathrm{g} / \mathrm{d})\end{array} \\ \text { Basal diet: } & & \\ \text { + DL-threonine } & 5 \cdot \mathrm{I} & 27.58 \\ \text { + L-tryptophan } & 2 \cdot \mathrm{I} & 11 \cdot 29 \\ \text { + DL-methionine } & 2 \cdot 2 & \mathrm{II} \cdot 97 \\ \text { + DL-isoleucine } & 5.8 & 3 \mathrm{I} \cdot 47\end{array}$

Table 2. The effect of dietary lysine level on the concentration $(\mu \mathrm{mol} / \mathrm{ml})$ of plasma amino acids in lactating sows $\uparrow$

\begin{tabular}{|c|c|c|c|c|c|c|c|c|}
\hline \multirow[b]{2}{*}{ Amino acid } & \multicolumn{6}{|c|}{ Dietary lysine (g/kg DM) } & \multirow{2}{*}{$\begin{array}{l}\text { SE for } \\
\text { comparison } \\
\text { of treatment } \\
\text { means }\end{array}$} & \\
\hline & 3.7 & $5 \cdot 7$ & $7 \cdot 7$ & $9 \cdot 7$ & $11 \cdot 7$ & $13 \cdot 7$ & & \\
\hline $\begin{array}{l}\text { Aspartic acid } \\
\text { Threonine }\end{array}$ & $\begin{array}{l}0.025 \\
0.175\end{array}$ & $\begin{array}{l}0.023 \\
0.091\end{array}$ & $\begin{array}{l}0.023 \\
0.080\end{array}$ & $\begin{array}{l}0.023 \\
0.082\end{array}$ & $\begin{array}{l}0.020 \\
0.073\end{array}$ & $\begin{array}{l}0.019 \\
0.063\end{array}$ & $\begin{array}{l}0.0023 \\
0.0084\end{array}$ & $\underset{* * *}{N S}$ \\
\hline Serine & 0.162 & 0.148 & 0.117 & 0.141 & 0.137 & 0.149 & 0.0116 & NS \\
\hline Glutamic acid & $0.35 \mathrm{I}$ & 0.446 & 0.373 & 0.384 & 0.286 & 0.284 & 0.0417 & NS \\
\hline Proline & 0.784 & 0.723 & 0.607 & 0.637 & 0.478 & 0.635 & 0.0817 & NS \\
\hline Glycine & 0.797 & 0.863 & 0.712 & 0.765 & 0.803 & 0.917 & 0.0563 & NS \\
\hline Alanine & 0.901 & 0.899 & $0.88 \mathrm{I}$ & 0.870 & 0.944 & 1.00 & 0.0654 & NS \\
\hline Valine & 0.416 & 0.415 & 0.353 & 0.390 & 0.388 & 0.382 & 0.0254 & NS \\
\hline Cystine & 0.114 & 0.135 & 0.123 & 0.151 & 0.120 & 0.113 & 0.0093 & NS \\
\hline Methionine & 0.049 & 0.042 & 0.038 & 0.039 & 0.034 & 0.033 & 0.0031 & $*$ \\
\hline Isoleucine & 0.137 & 0.132 & 0.122 & 0.130 & 0.125 & 0.117 & 0.009 & NS \\
\hline Leucine & 0.213 & 0.198 & 0.164 & 0.193 & 0.171 & 0.155 & 0.0148 & NS \\
\hline Tyrosine & 0.130 & 0.107 & 0.092 & 0.093 & 0.075 & 0.078 & 0.0048 & $* * *$ \\
\hline Phenylalanine & 0.135 & 0.120 & $0 \cdot 103$ & 0.117 & 0.099 & 0.102 & 0.0074 & $*$ \\
\hline Lysine & 0.050 & 0.115 & 0.197 & 0.251 & 0.692 & 0.757 & 0.0709 & *** \\
\hline Histidine & 0.050 & 0.070 & 0.038 & 0.037 & 0.054 & 0.049 & 0.0087 & NS \\
\hline Arginine & 0.080 & 0.090 & 0.096 & 0.087 & 0.152 & 0.103 & 0.0188 & NS \\
\hline Ornithine & 0.047 & 0.078 & 0.057 & 0.062 & 0.079 & 0.082 & 0.0113 & NS \\
\hline Tryptophan & 0.163 & 0.155 & 0.166 & $0 \cdot 184$ & 0.159 & 0.193 & 0.0187 & NS \\
\hline
\end{tabular}

All sows received $4.5 \mathrm{~kg}$ diet each morning allowing $\mathrm{I} \cdot 8 \mathrm{~kg}$ for the sow and $0.45 \mathrm{~kg} /$ piglet suckled. Water was provided ad lib. Piglets were free to suckle at all times including sampling days. Each sow was allocated to each treatment in a randomized manner. Each treatment was offered for a period of $3 \mathrm{~d}$. There were six treatment periods and each sow received each treatment in a random manner. Blood samples were collected on day 3 of each treatment at $\mathrm{I}$ and $4 \mathrm{~h}$ after feeding. The experiment started on day $\mathrm{I} 2$ and terminated on day 30 of lactation. The methods used in this and the following experiment for blood collection and sampling have been described previously (Sohail, Cole \& Lewis, 1978).

Expt. 2. Two Landrace $\times$ (Landrace $\times$ Large White) lactating sows were housed in the metabolism crates on the Ioth day of lactation. The litters were standardized to eight piglets per sow. The composition of the basal diet was the same as in Expt $\mathrm{I}$. The lysine content of the diet was increased to I I. $2 \mathrm{~g} / \mathrm{kg}$ DM and maintained at this level in all the treatments. The basal diet was supplemented with threonine, tryptophan, methionine or isoleucine (Table $\mathrm{I}$ ). The diets were fed to sows at the rate of $5.4 \mathrm{~kg} / \mathrm{d}$. The treatments were randomized and the 

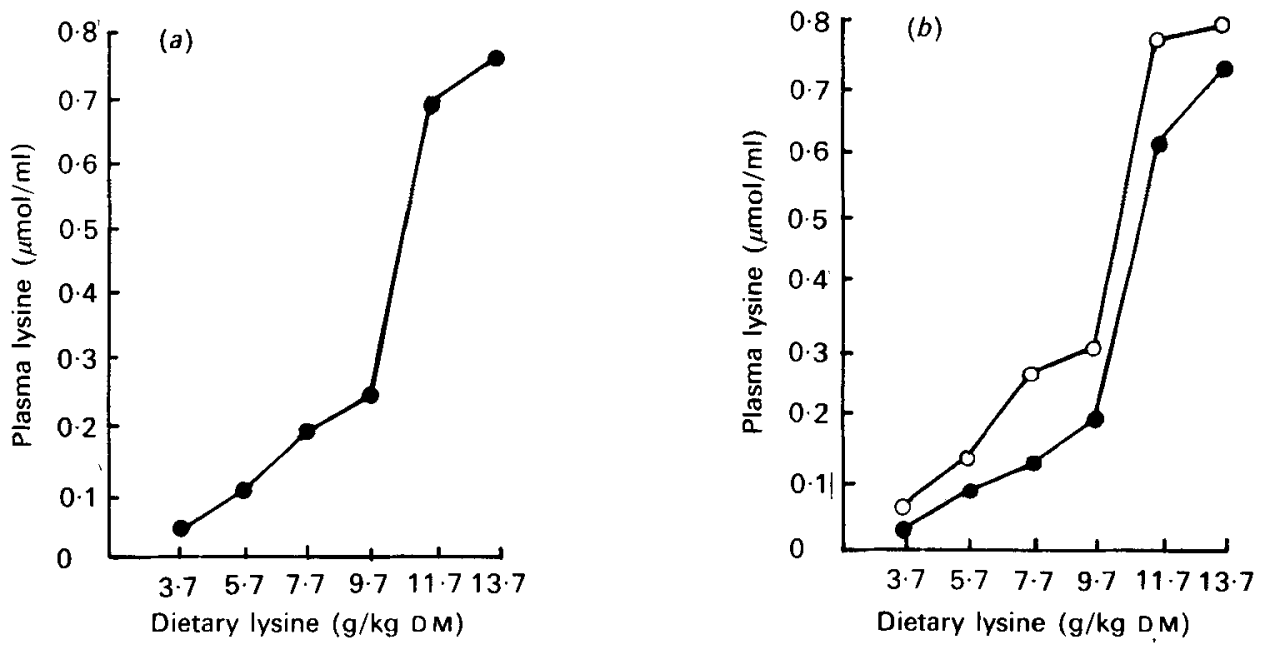

Fig. I. (a). The effect of dietary lysine level $(\mathrm{g} / \mathrm{kg}$ dry matter (DM)) on the concentration $(\mu \mathrm{mol} / \mathrm{ml})$ of plasma lysine; $(b)$ the effect of period after feeding $(O, \mathrm{I} \mathrm{h} ; \mathbf{0}, 4 \mathrm{~h})$ on the concentration of lysine in blood plasma $(\mu \mathrm{mol} / \mathrm{ml})$ of lactating sows (six piglets/sow) given graded levels of dietary lysine $(\mathrm{g} / \mathrm{kg} \mathrm{DM})$.

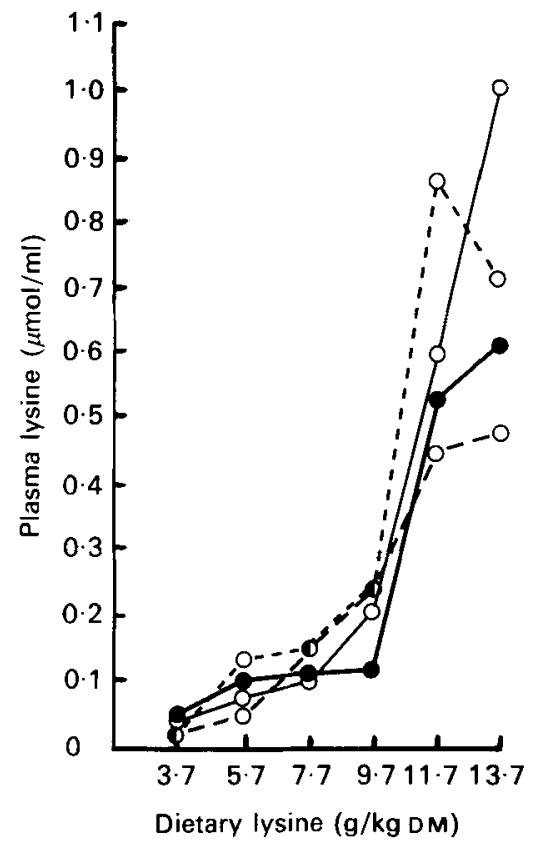

Fig. 2. Variation in plasma lysine response $(\mu \mathrm{mol} / \mathrm{ml})$ to graded levels of dietary lysine $(\mathrm{g} / \mathrm{kg}$ dry matter) between four lactating sows (six piglets/sow) determined $4 \mathrm{~h}$ after feeding. 
Table 3. The effect of dietary lysine level on the concentration (mmol/l) of blood urea in lactating sows*

\begin{tabular}{cccc}
$\begin{array}{c}\text { Dietary lysine } \\
\text { (g/kg DM) }\end{array}$ & \multicolumn{2}{c}{ Period after feeding (h) } & $\begin{array}{c}\text { Treatment' } \\
\text { means }\end{array}$ \\
\cline { 2 - 4 } 3.7 & 4 & 4 & 5.36 \\
5.7 & 4.95 & 5.78 & 4.58 \\
7.7 & 4.33 & 4.93 & 4.74 \\
9.7 & 3.58 & 5.16 & 4.05 \\
II.7 & 4.42 & 4.53 & 4.87 \\
I3.7 & 4.48 & 5.31 & 4.96 \\
'Period' means & 4.33 & 5.44 &
\end{tabular}

SE for comparison of means within treatment 0.103 , SE for comparison of means between treatments 0.219 .

DM, dry matter. "Six piglets/sow.

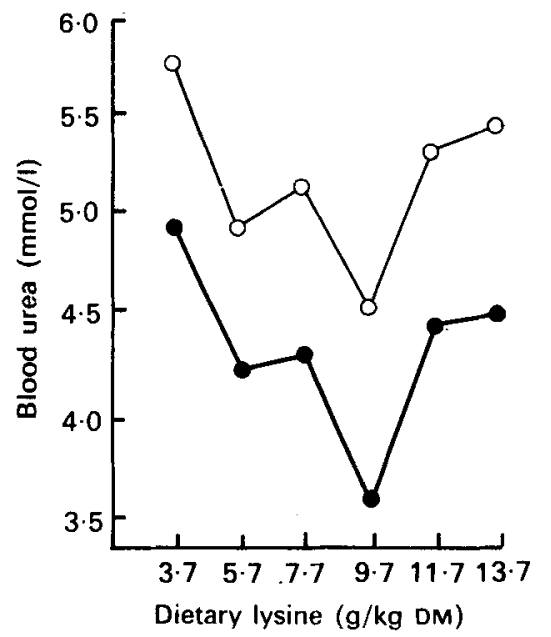

Fig. 3. The effect of dietary lysine level ( $\mathrm{g} / \mathrm{kg}$ dry matter (DM)) on the concentration (mmol/l) of blood urea in lactating sows (six piglets/sow) at $\mathrm{I}(\mathrm{O})$ and $4(\mathrm{O}) \mathrm{h}$ after feeding.

duration of each treatment was $3 \mathrm{~d}$. Each animal received each treatment. Blood samples were obtained on day 3 of each treatment at $4 \mathrm{~h}$ after feeding.

\section{RESULTS}

Expt $\mathrm{I}$. The effect of graded levels of dietary lysine on the concentration of amino acids in the blood plasma is given in Table 2. Plasma lysine values remained at a low level with supplementation up to $9.7 \mathrm{~g} / \mathrm{kg}$ diet and beyond this level there was a marked increase in the concentration of lysine in the plasma (Fig. $\mathrm{I} a$ ). The levels of plasma lysine were higher at $\mathrm{I} \mathrm{h}$ than at $4 \mathrm{~h}$ after feeding (Fig. $\mathrm{I} b$ ). The sampling interval had a significant $(P<0.01)$ effect on plasma lysine. Between-animal variation had no significant effect on plasma lysine concentration (Fig. 2).

The treatment means of blood urea levels at $\mathrm{I}$ and $4 \mathrm{~h}$ after feeding are given in Table 3 . The blood urea levels were significantly $(P<0.05)$ affected by the level of lysine in the diet. Blood urea levels decreased, though not quite consistently, with increase in dietary lysine up to $9.7 \mathrm{~g} / \mathrm{kg}$ diet and then increased with further increases in lysine intake. The sampling 
Table 4. Effect of supplementation of the basal diet with different essential amino acids on the concentration (umol/ml plasma) of free amino acids in the plasma of lactating sowst

Dietary treatment

\begin{tabular}{|c|c|c|c|c|c|c|}
\hline & Basal & $\begin{array}{l}\text { Basal+ } \\
\text { DL-threo- } \\
\text { nine }\end{array}$ & $\begin{array}{l}\text { Basal + } \\
\text { L-trypto- } \\
\text { phan }\end{array}$ & $\begin{array}{c}\text { Basal }+ \\
\text { DL-methio- } \\
\text { nine }\end{array}$ & $\begin{array}{l}\text { Basal+ } \\
\text { DL-iso- } \\
\text { leucine }\end{array}$ & $\begin{array}{l}\text { SE of dif- } \\
\text { ference for } \\
\text { comparison } \\
\text { of means }\end{array}$ \\
\hline Aspartic acid & 0.022 & 0.020 & 0.020 & 0.019 & 0.018 & 0.005 \\
\hline Threonine & 0.040 & 0.356 & 0.042 & $0.05 I$ & 0.032 & 0.035 \\
\hline Serine & 0.140 & 0.154 & 0.131 & 0.128 & 0.107 & 0.015 \\
\hline Glutamic acid & 0.147 & 0.195 & 0.090 & 0.104 & 0.115 & 0.054 \\
\hline Proline & 0.644 & 0.867 & 0.343 & 0.739 & 0.638 & 0.085 \\
\hline Glycine & 0.745 & $0.75^{8}$ & 0.716 & 0.669 & 0.690 & 0.046 \\
\hline Alanine & 0.660 & 0.761 & 0.641 & 0.667 & 0.476 & 0.082 \\
\hline Valine & 0.290 & 0.261 & 0.229 & 0.255 & 0.219 & 0.035 \\
\hline Cystine & 0.095 & 0.106 & 0.072 & 0.096 & 0.109 & 0.016 \\
\hline Methionine & 0.019 & 0.020 & 0.020 & 0.055 & 0.210 & 0.006 \\
\hline Isoleucine & 0.081 & 0.075 & 0.073 & 0.082 & 0.150 & 0.009 \\
\hline Leucine & O.I I I & 0.092 & 0.098 & 0.098 & 0.129 & 0.016 \\
\hline Tyrosine & 0.076 & 0.069 & 0.073 & 0.079 & 0.076 & 0.012 \\
\hline Phenylalanine & 0.060 & 0.083 & 0.069 & 0.075 & 0.094 & 0.012 \\
\hline Lysine & 0.664 & 0.657 & 0.531 & 0.706 & 0.702 & 0.087 \\
\hline Histidine & 0.085 & 0.085 & 0.062 & 0.071 & 0.071 & 0.017 \\
\hline Arginine & 0.162 & 0.167 & 0.130 & 0.172 & 0.171 & 0.033 \\
\hline Tryptophan & 0.075 & 0.055 & 0.102 & 0.081 & 0.058 & 0.011 \\
\hline Ornithine & 0.112 & 0.099 & 0.072 & 0.122 & 0.097 & $0.03 x$ \\
\hline
\end{tabular}

NS, not significant.

$* P<0.05,{ }^{* *} P<0.01, * * * P<0.001$.

$\dagger$ Six piglets/sow.

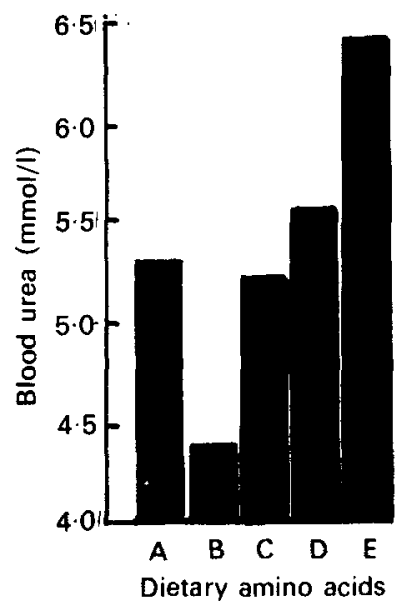

Fig. 4. Ine effect of supplementation of dietary essential amino acids on the blood urea levels (mmol/l) in lactating sows (six piglets/sow). Basal biet $+:$ (A) L-lysine; (B) +DL-threonine; (C) + L-tryptophan; (D) + DL-methionine; (E) + isoleucine.

interval had a significant $(P<0.001)$ effect on blood urea levels (Fig. 3). There was no significant interaction between treatment and sampling interval but the animal variation had a significant $(P<0.001)$ effect on blood urea levels.

Expt 2. The results of the amino acid analyses are summarized in Table 4. The only amino acids in plasma affected by the dietary treatments were threonine $(P<0.01)$, methionine $(P<0.00 \mathrm{I})$ and isoleucine $(P<0.00 \mathrm{I})$ which increased in plasma when there had been a 
Table 5. The effect of supplementation of the basal diet with different essential amino acids on the concentration ( $\mathrm{mmol} / \mathrm{l}$ ) of blood urea in lactating sows*

\begin{tabular}{|c|c|c|c|}
\hline \multirow[b]{2}{*}{ Dietary treatment } & \multicolumn{2}{|c|}{ Sow no. } & \multirow{2}{*}{$\begin{array}{c}\text { Treatment } \\
\text { means }\end{array}$} \\
\hline & $\mathbf{I}$ & 2 & \\
\hline $\begin{array}{l}\text { Basal: alone } \\
\text { + DL-threonine } \\
\text { + L-tryptophan } \\
\text { +DL-methionine } \\
\text { +DL-isoleucine }\end{array}$ & $\begin{array}{l}4 \cdot 95 \\
4 \cdot 35 \\
5 \cdot 00 \\
5 \cdot 68 \\
6 \cdot 11\end{array}$ & $\begin{array}{l}5 \cdot 74 \\
4 \cdot 49 \\
5 \cdot 52 \\
5 \cdot 49 \\
6 \cdot 81\end{array}$ & $\begin{array}{l}5 \cdot 34 \\
4 \cdot 42 \\
5 \cdot 26 \\
5 \cdot 59 \\
6 \cdot 46\end{array}$ \\
\hline 'Sow' means & $5 \cdot 22$ & $5 \cdot 6 I$ & \\
\hline
\end{tabular}

SE of difference for comparison of means between treatments 0.290 , sE of difference for comparison of means between animals 0.183 .

* Six piglets/sow.

corresponding increase in the dietary level. Plasma tryptophan did show an increase in the plasma as a result of the dietary supplement but this increase was not statistically significant. Plasma lysine was not affected by the dietary treatments.

The results of the blood urea analyses for both sows are given in Table 5. Blood urea levels were significantly $(P<0.05)$ affected by the dietary treatments (Fig. 4). Urea levels decreased sharply when diets supplemented with threonine were fed but increased when diets were supplemented with either isoleucine, methionine or tryptophan.

\section{DISCUSSION}

Information on the lysine requirement of the lactating sow is limited and the results reported are variable. The cause of this variability lies with the response criteria, the composition of the diets and the various types of animal used. Boomgaardt, Baker, Jensen \& Harmon (1972) based their estimates on the reproductive performance of Ist-litter sows fed ad lib. Their results indicated that reproductive performance as measured by the number of piglets born and piglet weight gain up to $2 \mathrm{I} d$ of age was not affected by increasing the level of dietary lysine above $6.0 \mathrm{~g} / \mathrm{kg}$ diet but that lactation weight loss was higher with 6.0 and $7.0 \mathrm{~g}$ dietary lysine $/ \mathrm{kg}$ than with higher levels. In contrast, Salmon-Legagneur \& Duee (1972) showed that piglet weight gain up to $21 \mathrm{~d}$ of age was the only sow performance criterion which was affected by the dietary level of lysine. Piglet weight gain was higher when the sows were given $6.9 \mathrm{~g}$ lysine $/ \mathrm{kg}$ diet than those at $5 . \mathrm{I}$ and $6.2 \mathrm{~g} / \mathrm{kg}$ diet. Lewis \& Speer (1973), on the other hand, took a different approach. These authors based their estimates on nitrogen retention, plasma lysine, plasma urea, milk composition, milk yield and piglet weight gain. None of the criteria showed close agreement with each other. The sows remained in negative $\mathrm{N}$ balance with up to $4.8 \mathrm{~g}$ dietary lysine $/ \mathrm{kg}$ diet and in positive $\mathrm{N}$ balance only at 6.6 and $9.0 \mathrm{~g}$ dietary lysine $/ \mathrm{kg}$ diet. It would appear that one of the main differences between experiments is the level of food intake. Consequently, the optimum lysine requirements reported by various workers are presented in Table 6 as daily intakes.

The relationship between the plasma amino acid levels and the amino acid adequacy of a diet is well documented (e.g. Puchal, Hays, Speer, Jones \& Catron, I962; Zimmerman \& Scott, 1965) and Mitchell, Becker, Jensen, Harmon \& Norton (I968) suggested that plasma amino acid levels can provide a better means than $\mathrm{N}$ retention of assessing the amino acid status of the animal. In the present study, plasma lysine did not accumulate in plasma with supplements of up to $9.7 \mathrm{~g}$ dietary lysine $/ \mathrm{kg}$ DM but beyond this level a rapid and almost linear increase occurred in plasma lysine (Fig. I $a$ ). Blood urea levels decreased as the amino 
Table 6. Estimates of lysine requirement in lactating sows

\begin{tabular}{|c|c|c|c|}
\hline Source & $\begin{array}{c}\text { Lysine } \\
(\mathrm{g} / \mathrm{d})\end{array}$ & $\begin{array}{l}\text { Food intake } \\
\qquad(\mathrm{kg} / \mathrm{d})\end{array}$ & Criteria used \\
\hline Baker, Becker, Jensen \& Harmon (1970) & $32 \cdot 4^{*}$ & 4.0 & Reproductive performance \\
\hline $\begin{array}{l}\text { Boomgaardt, Baker, Jensen \& Harman } \\
\text { (1972) }\end{array}$ & 200 & $3 \cdot 3$ & Reproductive performance \\
\hline Lewis \& Speer (1973) & $30 \cdot 5$ & $5 \cdot 45$ & $\begin{array}{l}\text { Nitrogen retention and } \\
\text { milk protein }\end{array}$ \\
\hline Mahan, Becker \& Jensen (1971) & $37 \cdot 8^{*}$ & 4.5 & $\mathbf{N}$ balance \\
\hline Salmon-Legagneur \& Duee (1972) & $37 \cdot 4$ & $5 \cdot 42$ & $\begin{array}{l}\text { Performance of the pig- } \\
\text { lets and blood urea }\end{array}$ \\
\hline Present study & $38 \cdot 4$ & $4 \cdot 5$ & $\begin{array}{l}\text { Plasma amino acids and } \\
\text { blood urea level }\end{array}$ \\
\hline
\end{tabular}

acid balance was improved and then increased with further increase in lysine intakes. The magnitude of the increase is perhaps a little surprising. Considering both responses, the results suggest that lysine intake above $38.4 \mathrm{~g} / \mathrm{d}$ was probably in excess of the requirement level. Plasma threonine showed a decrease with each increment in dietary lysine (Table 2). This, however, does not appear to be unique for threonine since methionine and tyrosine also behaved in a similar manner but to a lesser extent. The decrease in these amino acids probably was associated with the increased demand for milk protein synthesis.

Results of the second experiment showed that when lysine was held constant at a level which ensured that it was not limiting, addition of threonine, methionine, isoleucine or tryptophan to the diet led to the accumulation of that amino acid in the plasma. The nonsignificant increase in plasma tryptophan may indicate its relative insufficiency in the diet. It was of interest to note that both sows showed a decrease in blood urea when fed on the diet supplemented with DL-threonine. This agrees with the findings of Platter, Peo, Vipperman \& Cunningham (1973), who reported that growing pigs fed on diets containing high levels of threonine had significantly lower $(P<0.05)$ blood serum urea-N than pigs fed on low threonine diets. Muller, Rozman \& Hejziar (1969) reported that with cereal-based diets supplemented with amino acids, threonine appeared to be the second limiting amino acid when the diets were based on barley and wheat but tryptophan became second limiting when wheat was replaced by maize.

The rapid accumulation of threonine in the plasma was presumably due to the provision of the D-isomer as well as the L-isomer. Moreover in metabolic terms threonine is fairly resistant to deamination and not readily catabolized: it might therefore be expected to accumulate in the plasma if present in amounts slightly above the requirement level. Due to the differences in the plasma amino acid and blood urea response it is difficult to arrive at a firm conclusion but there may be a situation such that both tryptophan and threonine are close to limitation, depending on the general dietary circumstances.

The authors gratefully acknowledge the support by the Agricultural Research Council during the course of this study. Appreciation is also expressed to $\mathrm{Mr} \mathrm{H}$. L. Back for advice on statistical analysis and $\mathrm{Mr} \mathrm{J}$. Coote for technical assistance. 


\section{REFERENCES}

Agricultural Research Council (1967). The Nutrient Requirements of Farm Livestock. No. 3. Pig. London: H.M. Stationery office.

Baker, D. H., Becker, D. E., Jensen, A. H. \& Harmon, B. G. (1970), J. Anim. Sci. 30, 364.

Boomgaardt, J., Baker, D. H., Jensen, A. H. \& Harmon, B. G. (1972). J. Anim. Sci. 34, 408.

Elsley, F. W. H. \& MacPherson, R. M. (1972). In Pig Production, p. 417 [D. J. A. Cole, editor]. London: Butterworths.

Lewis, A. J. \& Speer, V. C. (1973). J. Anim. Sci. 37, 104.

Mahan, D. C., Becker, D. E. \& Jensen, A. H. (1971). J. Anim. Sci. 32, 476.

Mitchell, J. R., Becker, D. E., Jensen, A. H., Harmon, B. G. \& Norton, H. W. (1968). J. Anim. Sci. $27,1327$.

Muller, Z., Rozman, J. \& Hejziar, Z. (1969). Int. Aminosauren Symp., Rostock, p. 47.

Platter, P. D., Peo, E. R. Jr, Vipperman, P. E. \& Cunningham, P. J. (1973). J. Anim. Sci. $37,514$.

Puchal, F., Hays, V. W., Speer, V. C., Jones, J. D. \& Catron, D. V. (I962). J. Nutr. 76, 11.

Salmon-Legagneur, E. \& Duee, P. H. (1972). J. Rech. Porcine, pp. 157-16I.

Sohail, M. A., Cole, D. J. A. \& Lewis, D. (1974). Proc. Br. Soc. Anim. Prod. 3, I Io (Abstr.).

Sohail, M. A., Cole, D. J. A. \& Lewis, D. (1978). Br. J. Nut. 39, 463.

Speer, V. C. (197I). Feedstuffs, Minneapolis 43, 29.

Zimmerman, R. A. \& Scott, H. M. (1965). J. Nutr. 87, 13. 